\title{
Conflict Management Strategies and Administrative Effectiveness among Tertiary Institutions in Sokoto Metropolis
}

\author{
Lateef Adeyemi Yusuf $^{1, *}$, Yahaya Ibrahim ${ }^{1}$ \\ ${ }^{1}$ Department of Educational Foundations, Faculty of Education, Sokoto State University \\ [*Corresponding author: adedeyemi88@gmail.com]
}

\begin{abstract}
This paper examined conflict management strategies and administrative effectiveness in tertiary institutions in Sokoto metropolis. The study employed a correlational survey research design with questionnaire as the instrument of data collection. The population comprised all the eight tertiary institutions in the area. A sample of 168 lecturers were selected as respondents across four tertiary institutions. Two researcher developed instruments titled "Conflict Management Strategies Questionnaire" (CMSQ) and "Administrative Effectives Scale" (AES), with reliability indices of 0.82 and 0.85 respectively, were used for data collection. Data were analysed using Multiple Regression Analysis. The study established a significant relationship between dialogue, competition, prevention, and communication on one hand and administrative effectiveness on the other hand. It is recommended that tertiary institutions institutionalize dialogue as a conflict management strategy because through dialogue, team members develop skills to think together and to accept differences, thereby avoiding crises and improving performance.
\end{abstract}

Keywords: Conflict; Performance management; Tertiary institutions.

\section{$1 \quad$ Introduction}

People in organisations deal with conflict daily, Educational leaders are not exempted. In the past, educational institutions in Nigeria had few conflicts and controversies. Today, however, conflicts in these institutions are widespread. Therefore, it is reasonable to expect conflict in the administration of tertiary institutions in Sokoto metropolis. Conflicts usually occur between personnel on one hand and the school authorities on the other. Other forms of conflict include interpersonal conflict among staff and their students. Higher levels of conflict 
include Academic Staff Union of Universities (ASUU) and the Federal Government of Nigeria and the Nigeria Union of Teacher (NUT) and the State Government. This study was particularly relevant at a time when Academic Staff Union of Universities had to embark on a prolonged strike over non-revitalization of the university education system in Nigeria by the Federal Government.

Conflict has been defined in different ways. The commonest among these definitions holds that conflict is perceived divergence of interest. It is a belief that the current aspirations of the parties in a conflicting situation are incompatible (Pruit \& Kim, 2004). In a similar vein, Wallenstein (2007) defined conflict as "a social situation in which a minimum of two actors (parties) strive to acquire at the same moment in time an available set of scarce resources". Conflict could be described as all forms of opposition, disagreement, friction between two or more parties and it manifests in the form of arguments, protest, demonstration, aggression and other destructive behaviours. All these are common occurrences in organisations these days.

Differences in opinions and interest of the individual groups in the tertiary institutions may constitute conflict between staff and management, as well as students and school authority, hence management and personnel in institutions of higher learning sometimes engage themselves in conflict situations which result into strikes, thereby affecting university administration and consequently reducing productivity (Adeyemi \& Ademilua, 2012).

In the Nigerian university system, there had been claims of conflicts which had led to gradual but steady disruption of academic activities. Various forms of conflict occurs at varying degrees in universities. Amuseghan (2007), for instance, found that the level of occurrence of student-authority conflicts in the Canadian universities was high, while Oyebade (2000) and Awosusi (2005) reported that the level of occurrence of staff-authority conflicts in Nigeria tertiary institutions was also high. Folutile (2010) reported that there was a visitation panel inaugurated on March, 2009, to investigate the cause of the crisis that actually engulfed the University of Benin, when the university was deeply embroiled in crisis in 2009.

The cost of conflict includes direct cost, production cost, continuity cost and emotional cost (Nwofia, 2015). Also, no meaningful teaching-learning situation can take place in a conflict ridden academic environment. Unfortunately, most administrators in educational institutions are not knowledgeable in conflict management. Coupled with absence of clear procedures for conflict management in most tertiary institutions, this has contributed to the rate of conflicts in colleges and universities.

In Sokoto metropolis, the attitudes of administrators of tertiary institutions have not helped matters. Some of the conflicts centred on their personality and administrative styles. It is with this understanding that this Study undertook to examine the relationship between conflict management strategies and 
administrative effectiveness among public tertiary institutions in the area with, with a view to generating some recommendations towards attainment of the organizational goals of the institutions.

Demer (2002) and Adebayo (2007) identified dialogue, mediation, negotiation, reconciliation suppression and the use of force as conflict management strategies in organisations. Dialogue is "the art of thinking together" and is "sustained collective inquiry" into everyday experience and what we take for granted. Dialogue constructs a space for conversation that welcomes participants to invite a multiplicity of voices. It is intimately connected with the co-creation of new realities. Dialogue is meant to develop joint approaches to conflict resolution as well as improve relationships, understanding and trust between individuals or groups in conflict with one another. Prevention strategy is the object of a wide range of policies and initiatives. Its aim is to avoid violent escalation of a dispute. Communication is a method of resolving conflict among tertiary institutions whereby the management ensures that both staff and students are carried along the activities of the institutions (Umoren, 2001; Nwofia, 2015). Negotiation is essentially, the process that takes place within conflict resolution and guides the agreement resulting in the target goal, whether it is peace or better understanding. Within this context, negotiation skills implies ability to dialogue successfully. While mediation could be regarded as the process of providing intervention between conflicting parties to promote reconciliation, settlement or compromise. (Adomi \& Anie, 2005; Okotoni \& Okotoni, 2003)

Reconciliation is a multifaceted and ongoing process of building the relationships, alliances and social understandings that are necessary to support systemic changes. It is however more complex than just repairing relationships (Freeman, 2014; Shed, 2015). In a simple way, reconciliation is about establishing and maintaining a mutually respectful relationship between peoples. Although, there is a need for the awareness of the past, acknowledgement of the harm that has been inflicted and action to change behaviour.

Babalola (2004) defines effectiveness as the extent to which the goals and objectives of an institution are accomplished in relation to quality and quantity. In a similar vein, administrative effectiveness could be described as the extent to which an institution is able to achieve its institutional set goals.

The following hypotheses were formulated to guide the study:

$\mathrm{Ho}_{1}$ : There is no significant relationship between dialogue strategy and administrative effectiveness among tertiary institutions in Sokoto metropolis. $\mathrm{Ho}_{2}$ : There is no significant relationship between competition strategy and administrative effectiveness among tertiary institutions in Sokoto metropolis. $\mathrm{Ho}_{3}$ : There is no significant relationship between prevention strategy and administrative effectiveness among tertiary institutions in Sokoto metropolis $\mathrm{Ho}_{4}$ : There is no significant relationship between communication strategy and administrative effectiveness among tertiary institutions in Sokoto metropolis 


\section{$2 \quad$ Methodology}

The study followed a correlational survey research design, carried-out at ex-post facto, with questionnaire as the major instrument of data collection. Four tertiary institutions, namely, Sokoto State University, Shehu Shagari College of Education, Umaru Ali Shinkafi Polytechnic and College of Nursing and Midwifery were randomly selected for the study. Simple random sampling techniques were used to select 168 lecturers (respondents) across the institutions (i.e. 42 lecturers from each of the institutions). The sampled respondents were considered to be representatives of the entire population. The study is a typical questionnaire survey research. It is correlational because it seeks to establish relationships among the variables.

The population for the study comprises of all the academic staff in tertiary institutions, in Sokoto metropolis. There are eight public tertiary institutions in the area. Precisely, 168 questionnaires were administered through four trained research assistants. Only 160 of these questionnaires were found usable, representing a response rate of $95 \%$. The questionnaire, which was developed by the researcher, was tagged the "Conflict Management Strategies Scale (CMSC) and Administrative Effectiveness Scale (AES)". It was developed as a four-point Likert type rating scale, allowing the respondents to indicate whether they "Strongly Agree" $(\mathrm{SA})=4$, "Agree" $(\mathrm{A})=3$, "Disagree" $(\mathrm{D})=2$ or "Strongly Disagree" $(\mathrm{SD})=1$ with the statements in the instrument. The instrument was moderated by an expert in the field of educational management and psychology who affirmed its validity. Reliability indexes of 0.8 and 0.85 were established for the two parts of the instrument through a test-retest method at an interval of 3 weeks.

The data collected were analysed using multiple regression analysis. The hypotheses were tested at the .05 level of confidence.

\section{$3 \quad$ Findings}

$\mathrm{Ho}_{1}$ : There is no significant relationship between Dialogues Strategy and Administrative Effectiveness.

Table 1: Dialogue Strategy and Administrative Effectiveness

\begin{tabular}{lllllll}
\hline Variable & $\mathrm{N}$ & Mean & $\begin{array}{l}\text { Std. } \\
\text { Dev. }\end{array}$ & $\begin{array}{l}\mathrm{r}- \\
\text { Cal. }\end{array}$ & $\begin{array}{l}\mathrm{p}- \\
\text { Value }\end{array}$ & Decision \\
\hline $\begin{array}{l}\text { Dialogue strategy } \\
\begin{array}{l}\text { Administrative } \\
\text { Effectiveness }\end{array}\end{array}$ & 160 & 10.23 & 2.676 & .545 & .000 & Reject H0 \\
\hline
\end{tabular}


From the result in Table 1, Dialogue strategy and Administrative Effectiveness were positively related, $r(158)=.545, p=.000$. This indicates significant relationship between Dialogue Strategy and Administrative Effectiveness because the $p$-value is less than the .05 level of significance. Therefore, Ho which states that there is no significant relationship between Dialogue Strategy and Administrative Effectiveness was rejected.

$\mathrm{Ho}_{2}$ : There is no significant relationship between competition strategy and administrative effectiveness.

Table 2: Competition Strategy and Administrative Effectiveness

\begin{tabular}{lllllll}
\hline Variable & $\mathrm{N}$ & Mean & Std. Dev. & r-Cal. & p-Value & Decision \\
\hline Mediation strategy & 160 & 8.94 & 2574 & .387 & .000 & Reject $\mathrm{H}_{0}$ \\
$\begin{array}{l}\text { Administrative } \\
\text { Effectiveness }\end{array}$ & 160 & 18.83 & 4.864 & & & \\
\hline
\end{tabular}

From the result in Table 2, Competition Strategy and Administrative Effectiveness were positively related and significant $r(158)=0.387, p=.000$. This indicates significant relationship between Competition Strategy and Administrative Effectiveness because the $p$-value is less than the 0.05 level of significance. Therefore, $\mathrm{Ho}_{2}$ which states that there is no significant relationship between Competition Strategy and Administrative Effectiveness was rejected.

$\mathrm{Ho}_{3}$ : There is no significant relationship between Prevention Strategy and Administrative Effectiveness.

Table 3: Prevention Strategy and Administrative Effectiveness

\begin{tabular}{lllllll}
\hline Variable & $\mathrm{N}$ & Mean & Std. Dev. & r-Cal. & p-Value & Decision \\
\hline Prevention strategy & 160 & 11.8 & 3.202 & .371 & .000 & Reject $\mathrm{H}_{0}$ \\
Administrative & 160 & 18.83 & 4.864 & & & \\
Effectiveness & & & & & & \\
\hline
\end{tabular}

From the result in the Table 3, Prevention Strategy and Administrative Effectiveness were positively related and significant, $r(158)=.371, p=.000$. This indicates significant relationship between Prevention Strategy and Administrative Effectiveness, because $p$-value is less than .05 level of significance. Therefore, $\mathrm{Ho}_{3}$ which states that there is no significant relationship between Prevention Strategy and Administrative Effectiveness was rejected.

$\mathrm{Ho}_{4}$ : There is no significant relationship between Communication Strategy and Administrative Effectiveness.

Table 4: Communication Strategy and Administrative Effectiveness

\begin{tabular}{lllllll}
\hline Variable & $\mathrm{N}$ & Mean & Std. Dev. & r-Cal. & $\mathrm{p}$-Value & Decision \\
\hline Communication strategy & 160 & 9.62 & 2.376 & .327 & .000 & Reject Ho \\
Administrative Effectiveness & 160 & 18.83 & 4.864 & & & \\
\hline
\end{tabular}


From the result in Table 4, Communication Strategy and Administrative Effectiveness were positively related and significant, $r(158)=0.327, p=.000$. This indicates significant relationship between Communication Strategy and Administrative Effectiveness because the $p$-value is less than the .05 level of significance. Therefore, $\mathrm{Ho}_{4}$ which states that there is no significant relationship between Communication Strategy and Administrative Effectiveness was rejected.

\section{Discussion}

Findings from Table 1 indicated that dialogue strategy and administrative effectiveness were positively related and significant. This implies a reasonable degree of association between dialogue as a conflict management strategy and college administrative effectiveness. Based on the result it could be argued that, through dialogue, the team members probably develop skills to think creatively together to understand alternative ways and willingness to accept differences. This finding is in line with that of Aja (2013) that dialogue session offered the team a relative sense of psychological safety. It also corroborates Benson (2016)'s view that without dialogue, individuals and groups can neither exchange ideas effectively, nor develop shared understanding. The study also supports the work of Ogunsanwo (2002) indicating that a "win-win" approach is the most effective conflict management style in order to prevent crises, thereby improving workers performance in an organization.

From the result of Table 2, Competition Strategy and Administrative Effectiveness were significantly related. This indicate a degree of association between competition as a conflict management strategy and administrative effectiveness in our colleges. Competition strategy involves the 'survival of the fittest' and win-lose method, without taking other party into consideration. The study support that of Yusuf (2012), that conflict created by competition will be productive because each participant will work hard to win, thereby enhancing some aspect of organizational performance. In some situations, school organization may stimulate conflict by placing individual employees or groups in competitive situations. Administrators may establish contests, incentive plans or bonuses because each participant will work hard to win thereby improving organisational performance.

From the result of Table 3, Prevention Strategy and Administrative Effectiveness were significantly and positively related. Workplace conflict is a fact of life in any organization, as long as people will compete for jobs, power recognition and security (Adomie and Anie, 2005). Therefore, the task of management is not to suppress or avoid conflicts, but to manage them in order to 
enhance and not to detract from organizational performance. The study actually support that of Adebayo (2007) that teachers and manager in various colleges and universities should promote the rule of law, promote human freedom and equity of justice. These values are essential in order to prevent destructive conflict within our school system. A peaceable school expression, and conflict resolution are taught and supported throughout the culture of the school.

From the result of Table 4, Communication Strategy and Administrative Effectiveness were positively related and significant. This necessary implies that there is need for free flow of information in our colleges and universities. Lack of access to information breeds rumours and invariably results into conflict. Adequate communication in turn reduces conflict and maximizes productivity. The study is in line with the submission of Olagunju and Eweniyi (2002), in their study of strategies in conflict resolution among organizational workers. They concluded that both male and female workers had the same positive view of using communication strategy to resolve conflicts. The study was a descriptive research design with 283 workers randomly selected in Ogun State of Nigeria. The view of Akinboye (2002), Fabunmi and Alimba (2010) was equally corroborative, the importance of emphatic communication through active listening in organizational conflict resolution cannot be over-emphasized.

However, with integrative conflict management strategies, such as dialogue and communication, there is often high confidence and trust among organizational members, there exists loyalty to the school organization in the achievement of institutional performance.

The following recommendations were generated from the findings;

1. Managers of tertiary institutions should institutionalize dialogue. They need to explore dialogue strategy as a foremost step among others in managing conflict. Through dialogue, team members develop skills to accept differences, thereby preventing crises and improve performance.

2. Managers of tertiary institutions should improve their communication skills and provide communication channels. Administrators should ensure free flow of information in our Colleges and Universities. They should be aware that lack of access to information breeds rumours and invariably results into crises.

3. Educational managers in tertiary institutions should try as much as possible to prevent frequent occurrence of conflict within the organization. They should note that a peaceable school results and they must ensure that values and skills of cooperation, tolerance are supported in the culture of the school.

4. Managers should try as much as possible to place individual employees or groups in a competitive stimuli to spark competition. Thereby making each participant to voluntary work hard to win. Administrators may establish contests, incentive plans or bonus. 


\section{References}

Adebayo, P. F. (2007). Student Crises: The dimension of student-police relation in Nigeria. Ilorin Journal of Education, 21(1) 75 - 84.

Adeyemi, T. O. \& Ademilua, S. O. (2012). Conflict management strategies and administrative effectiveness in Nigeria universities. Journal of Emerging Trends in Educational Research and Policy Studies, 3(3), 368-378.

Adomie, E. E. \& Anie, S. O. (2005). Conflict management in Nigeria university libraries. Journal of Library Management (27)8: 520 - 530. Retrieved from http:iiastonjournals.com/manuscripts/vo/2010/BEJ-15.

Aja, S. N. (2013). Conflict management approaches principles adopt for effective administration of secondary schools in Ebonyi State. International Journal of Science and Research.

Akinboye, J. O. (2002). Psychological principles for success in life and workplace. Ibadan: Stirling Holder Publishers (Nig) Ltd.

Amuseghan, S. A. (2007). Peace and conflict studies: An introduction text. Akure: Stebak Books and Publishers.

Awosusi, O.O. (2005). Relationship between work alienation and industrial conflicts. PhD thesis - Academic Staff of Universities in South-West Nigeria. University of Ado-Ekiti, Nigeria.

Babalola, J. B. (2004). Quality assurance and child-friendly strategies for improving public schools effectiveness and teacher performance in a democratic Nigeria. In J. O. Fagbamiye, and J. B. Babalola, (Eds) pp. 303313. Management of primary and secondary education in Nigeria. Ibadan: NAEAP

Benson, I. D. (2016). Causes of conflict in our secondary schools and related unrest. Jos: Marx and Coy. Inc.

Demer, J. (2002). Settling international dispute. Retrieved online: http://www.deia.govlmen on $21^{\text {st }}$ February, 2001.

Fabunmi, M and Alimba, C. N. (2010) Conflict in school climate. A synopsis of its nature causes, effects and management approaches. African Journal of Educational Management 13(2).

Folutile, O. (2010). Panel re-affirms varsity's federal status. The Punch, Tuesday, June 15, 2010. P.37.

Freeman, V. (2014). In defence of reconciliation. Canadian Journal of Law and Jurisprudence, 27(1), $213-223$.

Nwofia, B. N. (2015). Conflict manifestation and management in secondary school in Ebonyi state, Nigeria. Unpublished PhD Thesis. Ebonyi State University, Abakaliki.

Ogunsanwo, O. A. (2002). Basic concepts in educational planning and administration. Ibadan: Spectrum Books Limited. 
Okotoni, O. \& Okotoni, A. (2003). Conflict management in secondary schools in Osun State, Nigeria. Nordic Journal of Africa Studies, 12(1):23 - 28. Retrieved from http://www.njas.helsinki.fi/pdf-files/vol12num1/okotoni.pdf

Olagunju, O. P., Ewemyi, G. B. (2002). Communication: A strategy in conflict resolution among organizational workers. The counsellor, 19(1).

Oyebade, E. F. (2000). Staff-authority conflict and management strategies in the institutions of higher learning in Ondo and Ekiti states. Unpublished $P h D$ thesis, Department of educational foundations and management, University of Ado-Ekiti.

Pruitt, D. G., Kim, S. H. (2004). Social conflict: Escalation, stalemate, and settlement. Boston: McGraw Hill.

Shed, R. (2015). Reconciliation. UM Today. Retrieved from http://news.manitoba.ca/reconciliation-nation.

Umoren, D. N. (2001). Comparative analysis of conflict management strategies among primary and post-primary school administrators in Uyo educational district of Cross Rivers State. International Journal of Educational Administration, Planning and Research (1) 115-124.

Wallenstein, P. (2007). Understanding conflict resolution. London: SAGE Publications.

Yusuf, L. A. (2012). School organizational conflict management in Nigeria. Sokoto Educational Review 13(11). 